\title{
Influence of Rough Flow over Sea Surface on Dry Atmospheric Deposition Velocities
}

\author{
Yan Zhang, Weichun $\mathrm{Ma}^{*}$, and Limin Chen \\ Shanghai Key Laboratory of Atmospheric Particle Pollution and Prevention (LAP3), Department of Environmental Science and \\ Engineering, Fudan University, Shanghai, China
}

Received 14 August 2012, accepted 9 May 2013

\begin{abstract}
A Meteorological model and a dry deposition module were used to estimate the effects of sea surface rough flow (SSRF) over the sea surface on dry deposition velocities. The dry deposition turbulence resistance, $R_{a}$, and sub-layer resistance, $R_{b}$, decreased more than $10 \%$ and $5 \%$ due to SSRF, respectively. For example, for $\mathrm{HNO}_{3}$, the mean dry deposition velocities $\left(\mathrm{V}_{\mathrm{d}}\right)$ were $0.51 \mathrm{~cm} \mathrm{~s}^{-1}$ in January, 0.58 in April, $0.65 \mathrm{~cm} \mathrm{~s}^{-1}$ in July and $0.79 \mathrm{~cm} \mathrm{~s}^{-1}$ in October with only smooth flow over the sea surface. However, the SSRF increased the $\mathrm{V}_{\mathrm{d}}$ of $\mathrm{HNO}_{3}$ by $5-20 \%$ in the east China seas. These results show that SSRF is an important factor in estimating surface roughness to further improve calculation of the dry deposition velocities over the ocean. Improvements in parameterization of sea roughness length will be a worthwhile effort in related future studies.
\end{abstract}

Key words: Sea surface rough flow, Dry deposition, Deposition resistance, Numerical model

Citation: Zhang, Y., W. Ma, and L. Chen, 2013: Influence of rough flow over sea surface on dry atmospheric deposition velocities. Terr. Atmos. Ocean. Sci., 24, 877-886, doi: 10.3319/TAO.2013.05.09.01(A)

\section{INTRODUCTION}

Terrestrial airborne pollutants are, as a matter of course, will be transported into the maritime atmosphere in different locales and deposited upon open sea surfaces. The deposition process depends on the turbulence of a marine atmospheric boundary layer and the characteristics of a sea surface. Much research has indicated that the roughness length is one of the main parameters which affect deposition processes and is of great importance for estimating the atmospheric deposition flux of a sea surface. Hertel et al. (1995) reported that dry deposition velocities of particles into the North Sea were lower than that upon land indicating a difference between land and water surfaces. However, the dry deposition velocities over an inland water surface usually were applied to calculate deposition fluxes to coastal water and open sea surfaces in many studies (Wan et al. 2002; Fu 2006). In fact, the deposition process on an open sea surface is very different from an inland water surface as characterized by wave and roughness lengths.

Early theoretical studies concerning an atmospheric deposition model focused on natural inland water surfaces.

\footnotetext{
* Corresponding author

E-mail:wcma@fudan.edu.cn
}

Slinn and Slinn (1980) built a deposition model suitable for natural waters considering the growth effect of particles with air humidity. Williams (1982) considered wave breaking, water droplets and the growth effect of particles in damp areas in a dry deposition model. In recent years, atmospheric deposition models have been developed and applied to estimate deposition flux over global and regional ocean surfaces (Asman and Janssen 1987; Andersen and Hovmand 1995; Ambelas et al. 2002; Jurado et al. 2004). Nho-Kim et al. (2004) calculated the dry deposition velocity of particles as a function of micro-meteorological conditions near the sea surface. Wang (2006) extended Williams' dry deposition model for application to a sea surface and took into consideration of the effects of wind speed, humidity, broken surface coverage and transfer coefficients. Qi et al. (2005) adopted a particle growth formula developed by Gerber (1985) to improve the above model and applied it to calculate the flux of trace metals in particles into the sea in Qingdao.

However, many atmospheric deposition models still have limitations in sufficiently considering sea surface parameters In an open marine boundary layer, sea surface roughness is not only the function of wind speed, or friction velocity, but also wave properties which can be calculated 
as a function of wave height, wave slope and wave age (Hsu 1974; Johnson et al. 1998; Smith et al. 1992). Taylor and Yelland (2001) considered the impact of waves on dynamic sea-surface roughness and built a parameterization scheme. Uz et al. (2002) conducted a series of flume experiments to study the wind-wave coupled system and calculated the contribution of waves to sea roughness length. Pan et al. (2005) confirmed the validity of Taylor's scheme in calculating sea roughness using buoy data in marine sites and pointed out that the effects of wave properties on sea roughness should be taken into consideration under high wind speed. Nowadays, most studies on atmospheric deposition over water surfaces have mainly concentrated on particle, very few involved a gaseous substance. However, the contribution of gaseous substances to deposition fluxes to sea surface has been shown to be very important (Rendell et al. 1993; De Leeuw et al. 2003; Zhang et al. 2010). The gaseous dry deposition process is greatly influenced by meteorological parameters and its temporal and spatial variation is significant (Gao and Wesely 1995; Ma and Daggupaty 2000; Zhang et al. 2004, 2007).

In view of the limitations mentioned above, this study tries to explore the effect of sea surface rough flow (SSRF) on dry deposition velocities of gaseous substances using a meteorological model and a dry deposition module. The East China Sea has been taken as an example.

\section{METHODOLOGY}

\subsection{Dry Deposition Model}

During the dry deposition process, the constant flux layer can be divided into turbulent, viscous and surface layers according to deposition height (Walcek 1986; Wesely 1989). Gaseous dry deposition velocity is determined by resistance in the turbulent layer $\left(R_{a}\right)$, viscous layer $\left(R_{b}\right)$ and surface layer $\left(R_{c}\right)$. $R_{b}$ is a drag force on pollutant deposition through the sheet flow layer near surface, reflecting the difference between mass and momentum transport within the layer.

For gaseous substances, Walcek et al. (1986) method is applied to calculate $R_{a}$; the land surface $R_{b}$ is calculated with the method used by Wesely (1989); and, the method developed by Hicks and Liss (1976) is adopted when calculating water surface $R_{b}$ as shown below.

$\mathrm{R}_{\mathrm{a}}=\frac{\ln \left(\mathrm{Z}_{\mathrm{r}} / \mathrm{Z}_{0}\right)-\psi_{\mathrm{c}}}{\mathrm{kU}_{*}}$

$\mathrm{R}_{\mathrm{b}}= \begin{cases}\frac{2}{\mathrm{kU}_{*}} \mathrm{~S}_{\mathrm{c}}^{2 / 3} & \text { (land surface, Wesely 1989) } \\ \frac{\ln \left(\mathrm{kU}_{*} \mathrm{Z}_{0} / \mathrm{D}_{\mathrm{g}}\right)}{\mathrm{kU}_{*}} & \text { (water surface, Hicks and Liss 1976) }\end{cases}$

where $Z_{r}$ is the height at which the dry deposition velocity is calculated, $Z_{0}$ stands for surface roughness length and is usually derived from empirical values according to localized topographic characteristics, $\psi_{c}$ is the revised stability function of mass. $U_{*}$ is the friction velocity; $S_{c}$ is the Schmidt number; and, $\mathrm{D}_{\mathrm{g}}$ is the molecular diffusivity.

$R_{c}$ is closely related to the biochemical reaction between pollutants and the deposition surface, which is dependent on the solubility, reactivity and the surface characteristics of the gas.

The dry deposition velocity $\mathrm{V}_{\mathrm{d}}$ can be calculated as:

$\mathrm{V}_{\mathrm{d}}=\frac{1}{\mathrm{R}_{\mathrm{a}}+\mathrm{R}_{\mathrm{b}}+\mathrm{R}_{\mathrm{c}}}$

\subsection{Parameterization of Sea Surface Roughness Length and Sensitivity Schemes}

Sea roughness, also called sea surface aerodynamic roughness length, is defined as the height at which wind speed equals zero above the sea surface. It depicts the micro-scale sea surface roughness, and the change illustrates the main characteristics of momentum transfer between the atmosphere and ocean to some extent. Sea roughness can seldom be directly observed. Since wind speed is easy to observe, sea surface roughness usually is parameterized as a function of wind speed.

Charnock (1955) proposed the classic water surface roughness scheme as $Z_{0}=Z_{c h} U_{*}^{2} / g$, where $U_{*}$ is the friction velocity; $g$ is the gravitational acceleration; and, $Z_{c h}$ stands for the Charnock parameter which characterizes the water surface properties. The value range of $Z_{c h}$ differs for lakes, limited surf zones and broad water surfaces. For the calculation of deposition resistances, the water roughness scheme recommended by Hicks and Liss (1976) was based on Charnock relation. In the Meteorology-Chemistry Interface Processor (MCIPv3.2) for Models3 Modeling System (Byun and Ching 1999), the calculation scheme for roughness is also based on Charnock's relation. In combination with Wu's (1982) research, the parameterization of $Z_{0}$ is calculated as $Z_{0}=0.0185 \mathrm{u}_{*}^{2} / \mathrm{g}+0.0001(\mathrm{~m})$, where the first term stands for rough flow and the second term represents smooth flow.

Hence, this study has introduced the Taylor and Yelland (2001) scheme into the deposition module to calculate the rough flow on sea surface aerodynamics roughness which includes the effects of wave height:

$\mathrm{Z}_{0 \mathrm{~s}}=1200 \mathrm{~h}_{\mathrm{s}}\left(\frac{\mathrm{h}_{\mathrm{s}}}{\mathrm{l}_{\mathrm{p}}}\right)^{4.5}+0.0001$

$\mathrm{h}_{\mathrm{s}}=0.018 \mathrm{U}_{10}^{2}\left(1+0.015 \mathrm{U}_{10}\right), \mathrm{l}_{\mathrm{p}}=\mathrm{t}_{\mathrm{w}} \mathrm{c}_{\mathrm{w}}$,

$\mathrm{t}_{\mathrm{w}}=0.729 \mathrm{U}_{10}, \mathrm{c}_{\mathrm{w}}=9.8 \mathrm{t}_{\mathrm{w}} / 2 \pi$

where $Z_{0 s}$ is sea surface roughness $(m), h_{s}$ is effective wave 
height, $1_{p}$ stands for wave length, $t_{w}$ is effective wave period and $c_{w}$ is effective wave phase velocity. Meanwhile, the effects of SSRF on friction velocity have been considered while calculating dry deposition velocity. The friction velocity is parameterized as below:

$$
\mathrm{U}_{*}=\frac{\mathrm{kU}}{\ln \left(\mathrm{Z}_{\mathrm{r}} / \mathrm{Z}_{0 \mathrm{~s}}\right)-\phi_{\mathrm{m}}(\xi)}
$$

where $\mathrm{U}$ is wind speed, $\phi_{\mathrm{m}}(\xi)$ is the stability function. The deposition module using the above sea surface roughness scheme has been used to simulate atmospheric nitrogen deposition to the east China seas (Zhang et al. 2010).

In this study, sensitivity tests were conducted under two different schemes for comparison to study the effects of sea surface rough flow on dry deposition processes. The sea surface roughness of Scheme one is fixed to $0.01 \mathrm{~cm}$, only considering smooth flow. Scheme two additionally included a dynamic parameterization term consider sea surface rough flow (SSRF), as listed in Eq. (4).

The sensitivity parameter in the deposition model shows that roughness has a direct impact on the turbulent and viscous layer resistance. Deposition resistance has corresponding changes in accord with seasonal and spatial variation of roughness which results in the changes of dry deposition velocities. In Eq. (7), $\Delta \mathrm{V}$ refers to the change ratio of the variables, $\mathrm{V}_{\text {surf }}$ is the variable with rough flow, $\mathrm{V}_{\text {non }}$ is the variable with only smooth flow (roughness $=0.01 \mathrm{~cm}$ ), where $\mathrm{V}$ can be referred as aerodynamic resistance $\left(\mathrm{R}_{\mathrm{a}}\right)$, viscous layer resistance $\left(\mathrm{R}_{\mathrm{b}}\right)$ and the dry deposition velocity of various pollutants $\left(\mathrm{V}_{\mathrm{d}}\right)$.
$\Delta \mathrm{V}=\frac{\mathrm{V}_{\text {surf }}-\mathrm{V}_{\text {non }}}{\mathrm{V}_{\text {non }}}$

\subsection{Meteorological Parameters}

Lin et al. (2004) reported that the meso-scale meteorological model MM5 performs well in simulating a sea surface wind field. In their results, the simulation deviation in $10-\mathrm{m}$ wind speed and wind direction above sea surface in the East China Sea was under 20\%. Thus in this study, the meteorological fields in January, April, July, October 2007 were calculated by MM5 to drive dry deposition module. The Lambert projection was used in this simulation. The physical processes schemes including Grell's cumulus parameterization scheme (Grell et al. 1994), MRF boundary layer scheme (Hong and Pan 1996), vapor scheme (Dudhia 1996), five-layer $(1,2,4,8,16 \mathrm{~cm})$ soil model and flexible boundary conditions were applied. The initial and boundary conditions were provided by $1^{\circ} \times 1^{\circ}$ reanalysis data with a time interval of $6 \mathrm{~h}$ from the European Centre for Medium-Range Weather Forecasts (ECMWF). Two domains were nested within the module as shown in Fig. 1. Domain 1 covers the entire land region of China and the East China Sea, with the center located at $\mathrm{N} 35^{\circ}, \mathrm{E} 105^{\circ}$. There are $55 \times 75$ grids in this domain with a $81-\mathrm{km}$ grid distance. Domain 2 covers eastern China including the sea, with $70 \times 70$ grids and a $27-\mathrm{km}$ grid distance. The terrain-following coordinate $(\sigma)$ is defined as the vertical coordinate with non-equidistant grids spreading in 24 layers; nearly half of the grids are distributed below $2 \mathrm{~km}$ in order to better illustrate the structure of the atmospheric boundary layer. There were 24 land-use

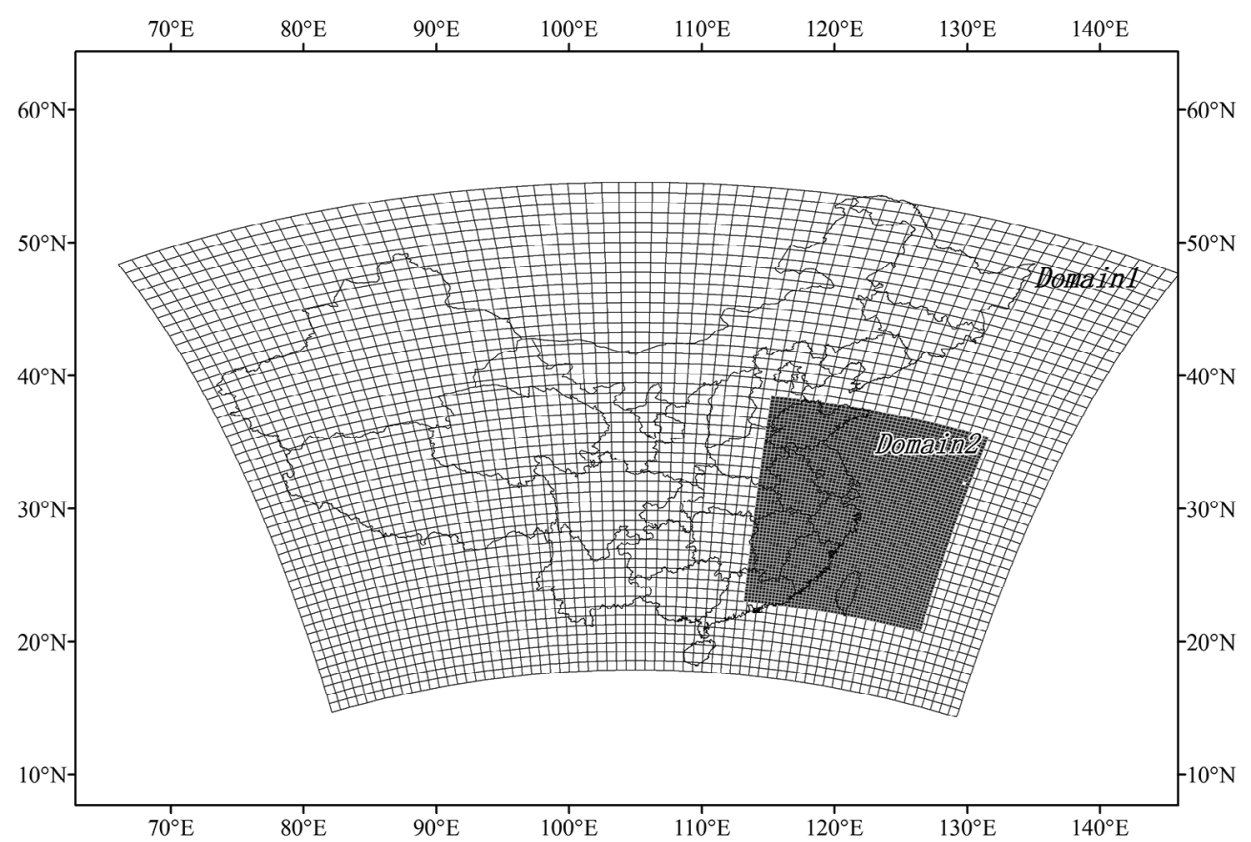

Fig. 1. Model domains. 
types from the USGS Satellite Dataset with a spatial resolution of 2' (about $3.7 \mathrm{~km}$ ) applied in the module.

Observational data of monthly mean of wind speed from two coastal meteorological sites, Lvsi (N32.06 ${ }^{\circ}$, E121.60 $\left.{ }^{\circ}\right)$ and Shengsi $\left(\mathrm{N} 29.60^{\circ}, \mathrm{E} 121.81^{\circ}\right)$ were used to validate the 10-m height wind speed simulated by MM5 (Fig. 2). Generally, the modeled wind agreed well with the observed ones. The correlation coefficients reached above 0.65 .

\section{RESULTS AND DISCUSSION}

\subsection{Spatial and Temporal Distribution of Sea Surface Roughness in the Eastern China Sea}

The spatial and temporal sea surface roughness has been estimated using the rough-flow parameterization scheme with the meteorological field as input data.

The mean monthly wind speed of each typical month varies greatly which is consistent with the results in the North-west and North Pacific Ocean, studied by Liu and Sun (2000) and Lin and Chen (2002), respectively. Generally, the average wind speed in fall and winter is greater than that of summer and spring. Figure 3 shows the distribution of mean sea surface roughness in typical months. In January, roughness length varied between 0.01 and $0.017 \mathrm{~cm}$ in most simulation regions with higher values of $0.02-0.022 \mathrm{~cm}$ occurring in the coastal region along Fujian Province due to integrated effects of cold high-pressure system and strait terrains. There were more significant spatial gradient in roughness in April and July, with southern high values in July and northern high roughness in April, both ranging from 0.011 to $0.018 \mathrm{~cm}$. In October, the sea surface roughness in dominant ocean areas was from 0.019 to $0.032 \mathrm{~cm}$, 2 to 3 times of the roughness of smooth surface and gradually decreasing from the southeast to northwest. In Bohai Bay, the roughness value was reduced to 0.011 to $0.022 \mathrm{~cm}$. In the southeast coastal regions, the mean sea surface roughness in October was highest in all typical months, which is in accordance with the seasonal variation of sea surface roughness using TOPEX altimeter wind data (Zhou and Guo 2005). This could be because of local tropical storms and synoptic convergence systems driving the enhancement of wind speed in the coastal region in October.
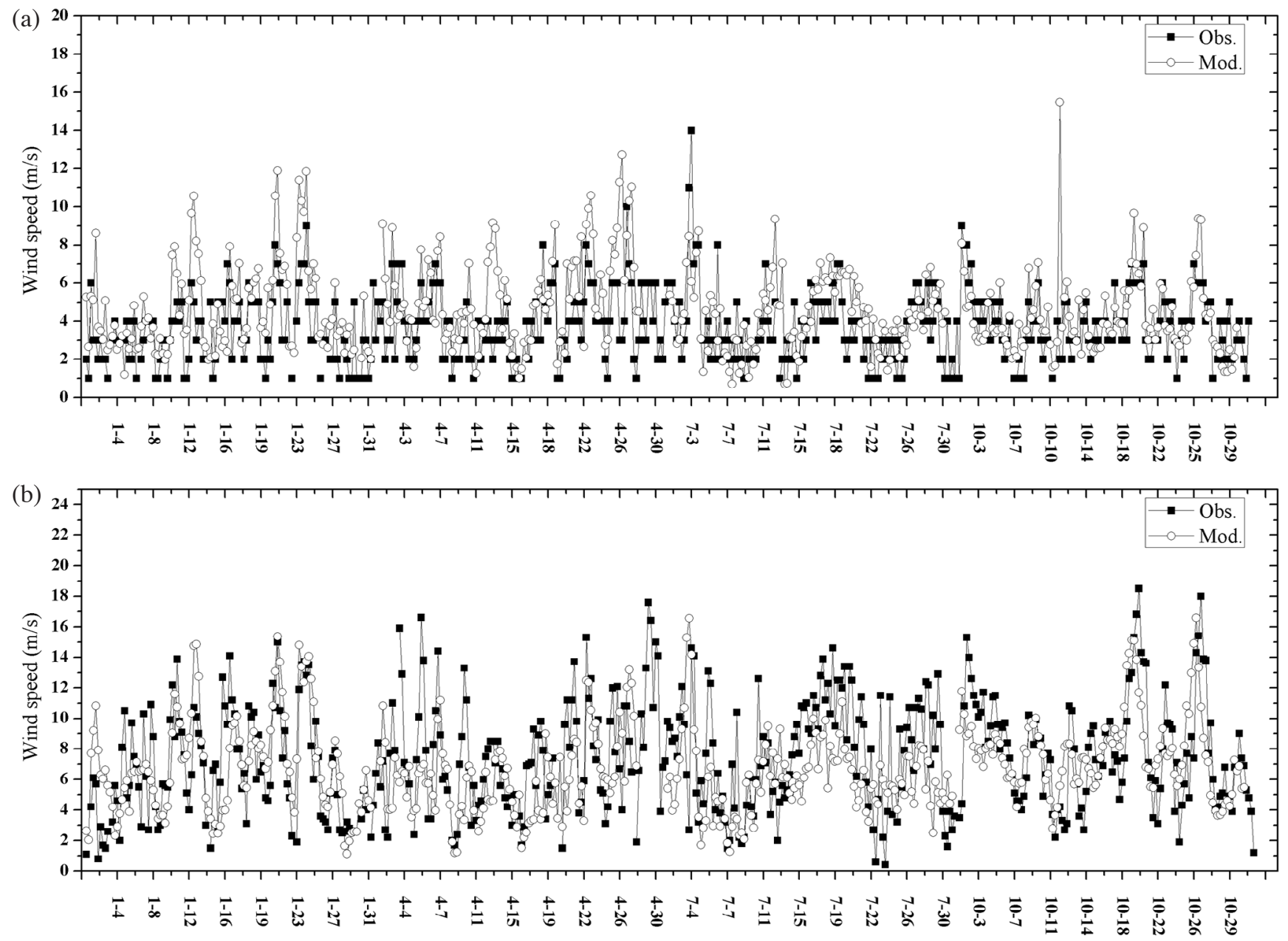

Fig. 2. Comparisons of simulated and observed 10-m wind speeds (a) Lvsi site, (b) Shengsi site. 
(a) $\quad 118^{\circ} \mathrm{E} \quad 120^{\circ} \mathrm{E} \quad 122^{\circ} \mathrm{E} \quad 124^{\circ} \mathrm{E} \quad 126^{\circ} \mathrm{E} \quad 128^{\circ} \mathrm{E} \quad 130^{\circ} \mathrm{E} \quad 132^{\circ} \mathrm{E}$

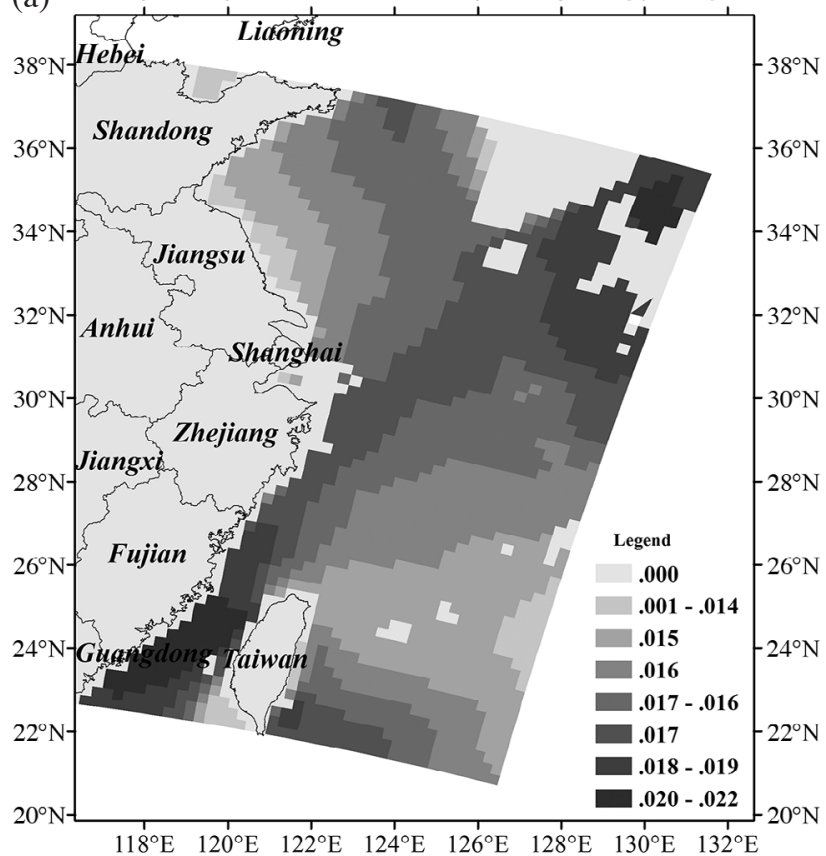

(c) $\quad 118^{\circ} \mathrm{E} \quad 120^{\circ} \mathrm{E} \quad 122^{\circ} \mathrm{E} \quad 124^{\circ} \mathrm{E} \quad 126^{\circ} \mathrm{E} \quad 128^{\circ} \mathrm{E} \quad 130^{\circ} \mathrm{E} \quad 132^{\circ} \mathrm{E}$

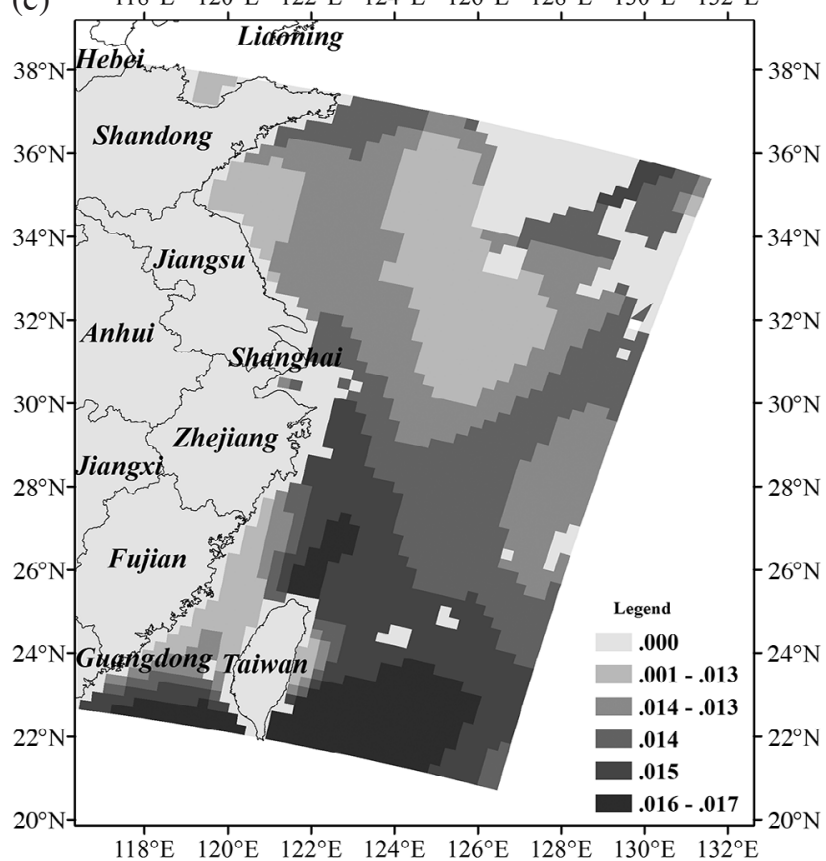

(b) $\quad 118^{\circ} \mathrm{E} \quad 120^{\circ} \mathrm{E} \quad 122^{\circ} \mathrm{E} \quad 124^{\circ} \mathrm{E} \quad 126^{\circ} \mathrm{E} \quad 128^{\circ} \mathrm{E} \quad 130^{\circ} \mathrm{E} \quad 132^{\circ} \mathrm{E}$

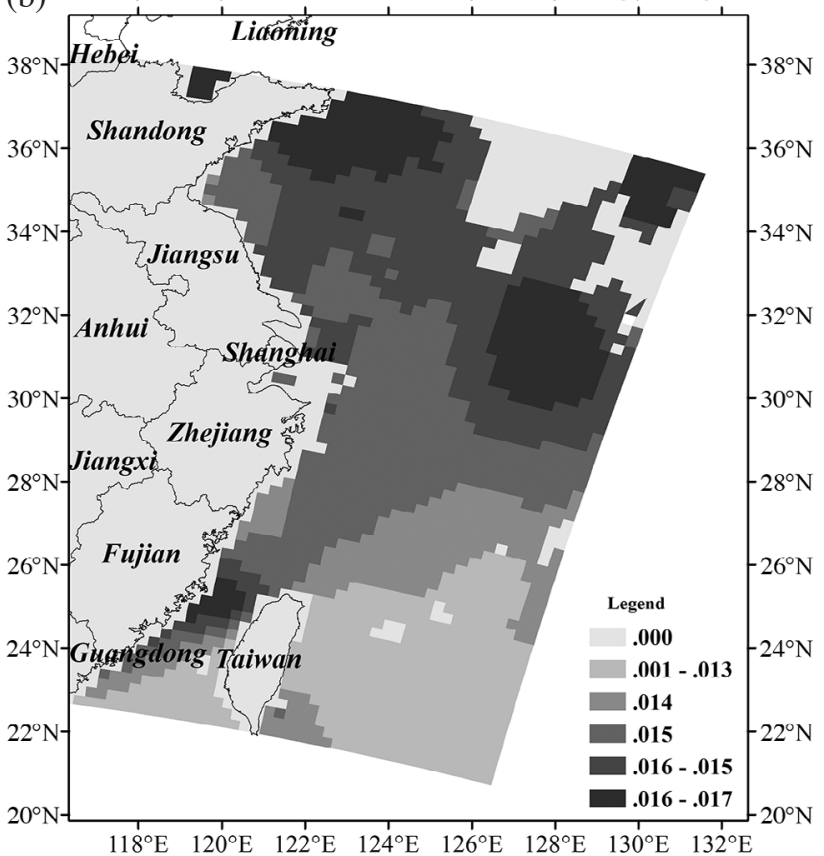

(d) $\quad 118^{\circ} \mathrm{E} \quad 120^{\circ} \mathrm{E} \quad 122^{\circ} \mathrm{E} \quad 124^{\circ} \mathrm{E} \quad 126^{\circ} \mathrm{E} \quad 128^{\circ} \mathrm{E} \quad 130^{\circ} \mathrm{E} \quad 132^{\circ} \mathrm{E}$

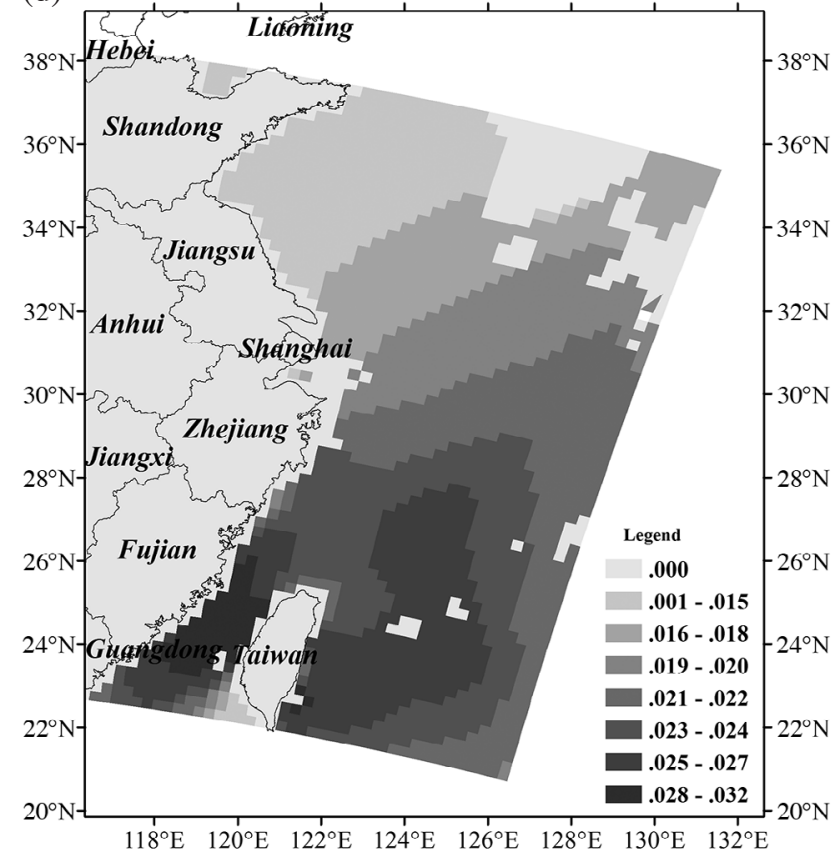

Fig. 3. Distribution of mean sea roughness lengths in typical months (cm) (a) January, (b) April, (c) July, and (d) October.

\subsection{Impact of Sea Surface Rough Flow on Dry Deposi- tion Resistances}

The aerodynamic resistance $R_{a}$ and viscous layer resistance $R_{b}$ in only smooth flow situation were shown in Table 1 as reference background to show the impact of rough flow on resistances. Impacts on aerodynamic resistance $R_{a}$ and viscous layer resistance $R_{b}$ were estimated when the variable $\mathrm{V}$ in Eq. (7) is replaced by $\mathrm{R}_{\mathrm{a}}$ and $\mathrm{R}_{\mathrm{b}}$, respectively.

Statistically, 1745 grids in a simulation domain were taken as sea region samples to estimate change ratios for $R_{a}$ and $R_{b}$ in different sea surface areas after considering SSRF (as in Fig. 4, only January and July were presented here). For $\mathrm{R}_{\mathrm{a}}$, the monthly average decrease were primarily distributed between 0.08 and 0.11 and decreased by around $10 \%$ in more than $80 \%$ of the sea surface in January. However, the change ratio in April is less than 0.10 within most sea surface, only $20 \%$ sea surface was reduced by more than 0.10 . The change ratio in July has an inhomogeneous spatial 
Table $1 . R_{\text {anon }}$ and $R_{\text {bnon }}$ without consideration of sea surface rough flow.

\begin{tabular}{|c|c|c|c|c|c|c|c|c|}
\hline & \multicolumn{4}{|c|}{$\mathbf{R}_{\text {anon }}\left(\mathbf{s ~ m}^{-1}\right)$} & \multicolumn{4}{|c|}{$\mathbf{R}_{\text {bnon }}\left(\mathbf{s ~ m}^{-1}\right)$} \\
\hline & Mean & Maximum & Minimum & Variance Std. & Mean & Maximum & Minimum & Variance Std. \\
\hline January & 173.1 & 206.1 & 114.6 & 15.78 & 45.8 & 55.1 & 29.3 & 4.55 \\
\hline April & 150.3 & 212.3 & 113.3 & 18.54 & 37.9 & 55.6 & 27.4 & 5.54 \\
\hline July & 136.6 & 223.5 & 111.0 & 12.58 & 34.0 & 56.7 & 27.7 & 2.92 \\
\hline October & 122.4 & 225.7 & 74.5 & 30.19 & 31.5 & 59.7 & 18.8 & 8.20 \\
\hline
\end{tabular}

(a)

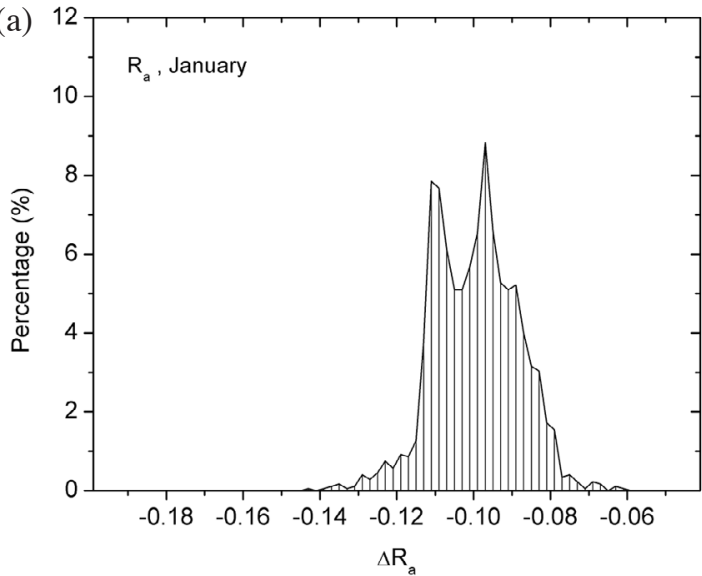

(c)

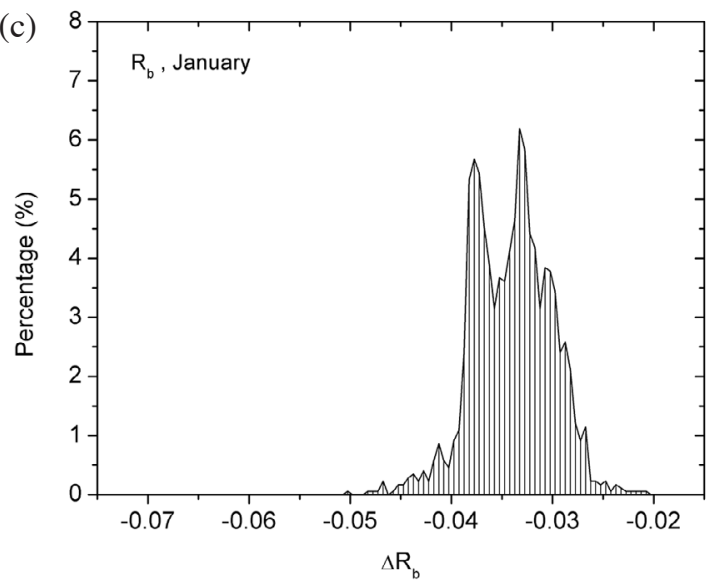

(b)

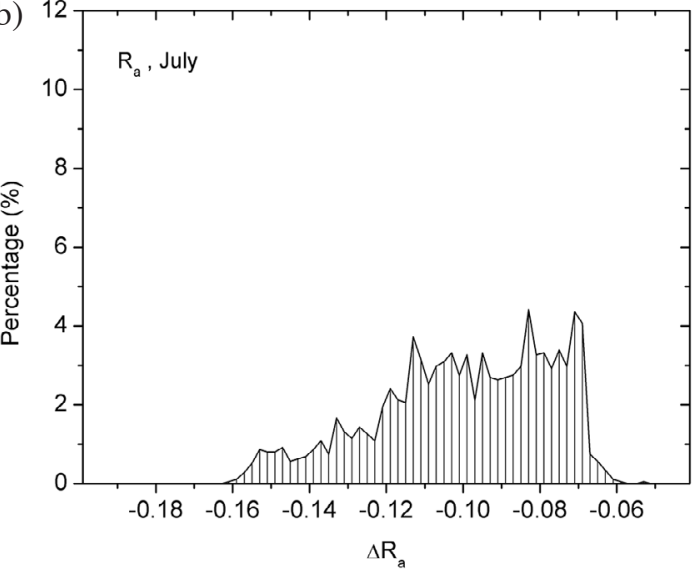

(d)

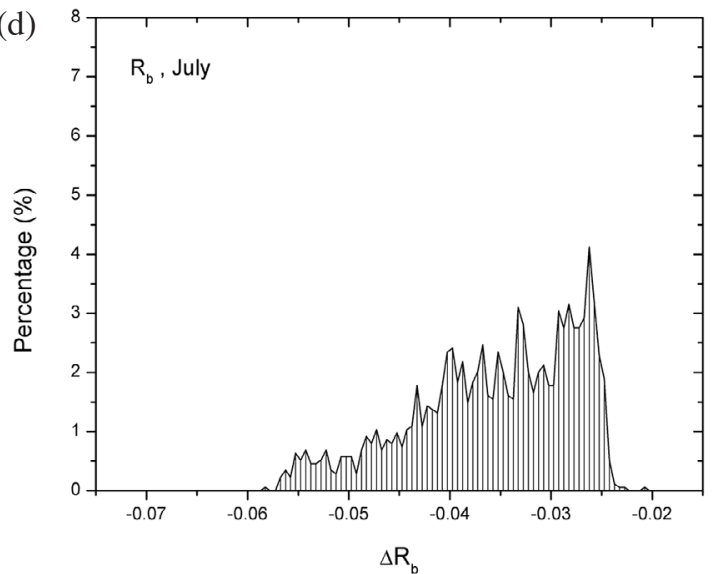

Fig. 4. Percentage of change ratio in all grids for $\mathrm{R}_{\mathrm{a}}$ in (a) January and (b) July and $\mathrm{R}_{\mathrm{b}}$ in (c) January and (d) July due to sea surface rough flow (Xaxis represents change ratio, $2 \%$ has been set as an interval and Y-axis represents percentage of grids with the change ratio in all grids).

distribution which varies from 0.05 to 0.16 ; but, each $2 \%$ change ratio section covered about $4 \%$ sea surface. The change situation in October distributed the widest range $0.05-0.19$ showing a significant spatial distribution, and $\mathrm{R}_{\mathrm{a}}$ in more than $60 \%$ of the sea surface decreased by more than $14 \%$. The seasonality of the $\mathrm{R}_{\mathrm{a}}$ change ratio was the result from the integrated impact of the change of sea surface roughness and friction velocity.

For $R_{b}$, the percentage of change ratio mainly ranged from $0.025-0.04$ in January and in $0.01-0.04$ in April. The highest change ratio in July and October reached 0.06 and 0.07 , respectively and the change ratio was mainly concentrated between 0.05 and 0.07 in October. All the change ratios in typical months were below 0.07 for $R_{b}$ which endured less impact by rough flows compared to $R_{a}$. In addition, as shown in Table 1 that $R_{a}$ is 4 - 5 times of $R_{b}$. Thus, the change in $\mathrm{R}_{\mathrm{a}}$ would account for the dominant contribution to the change in other resistances.

\subsection{Temporal and Spatial Distribution of Dry Depo- sition Velocity and Its Response to Sea Surface Rough Flow (SSRF)}

The deposition velocity $\mathrm{V}_{\mathrm{d}}$ of $\mathrm{HNO}_{3}$ is decided primarily by the aerodynamic $\left(\mathrm{R}_{\mathrm{a}}\right)$ and viscous layer $\left(\mathrm{R}_{\mathrm{b}}\right)$ resistance 
since surface resistance $\left(\mathrm{R}_{\mathrm{c}}\right)$ of $\mathrm{HNO}_{3}$ is rather small and it could be ignored during its deposition process to water surfaces (Walcek 1986; Zhang et al. 2004). Thus, $\mathrm{HNO}_{3}$ has been chosen as an example to explore the impact of SSRF on dry deposition velocity.

The dry deposition velocities of $\mathrm{V}_{\mathrm{d}}$ of $\mathrm{HNO}_{3}$ using smooth-flow scheme were presented in Figs. 5a and b. The dry deposition velocities $\mathrm{V}_{\mathrm{d}}$ of $\mathrm{HNO}_{3}$ distributed mainly between 0.5 to $4.5 \mathrm{~cm} \mathrm{~s}^{-1}$ over land regions. The modeled $\mathrm{V}_{\mathrm{d}}$ over land is in accord with the observed $\mathrm{V}_{\mathrm{d}}$ of $0-4.7 \mathrm{~cm} \mathrm{~s}^{-1}$ over grassland, $2.2-6.0 \mathrm{~cm} \mathrm{~s}^{-1}$ and 0.8 to $>20 \mathrm{~cm} \mathrm{~s}^{-1}$ for mixed forest (Huebert and Robert 1985; Meyers et al. 1989; Sievering et al. 2001). The deposition velocity of $\mathrm{HNO}_{3}$ to water surface is smaller than that to land surface with stronger turbulent activity above plant canopies. The $\mathrm{V}_{\mathrm{d}}$ varied from 0.3 to $0.7 \mathrm{~cm} \mathrm{~s}^{-1}$ on the eastern China sea surface, and higher in summer with the stronger turbulent activity making deposition easier than that in winter. The modeled $V_{d}$ over

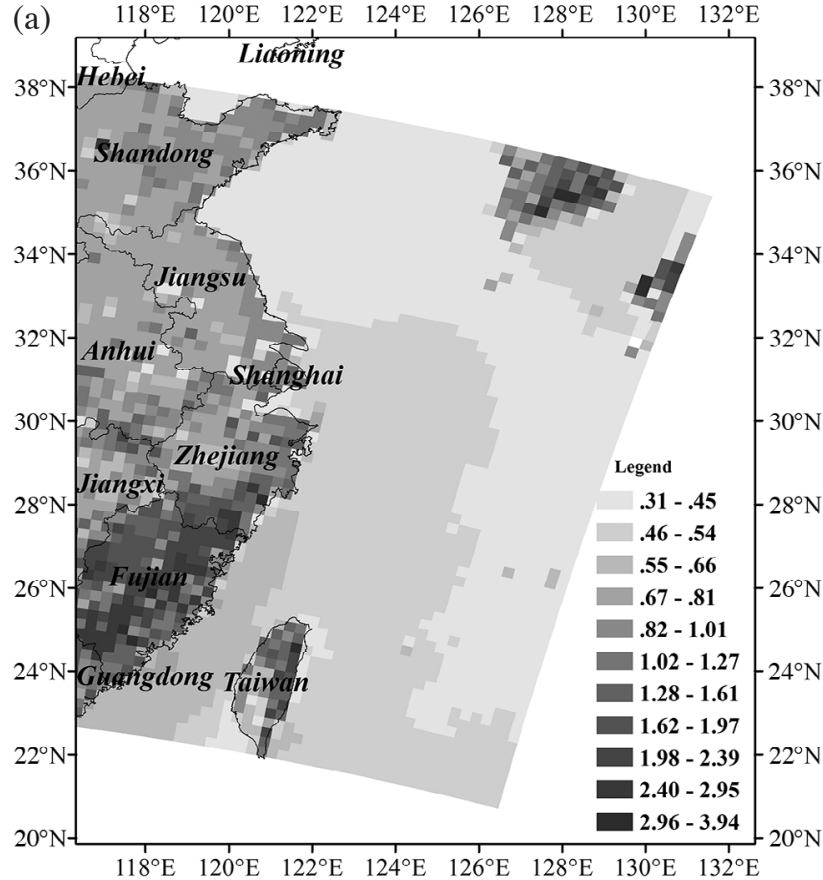

(c) $\quad 118^{\circ} \mathrm{E} \quad 120^{\circ} \mathrm{E} \quad 122^{\circ} \mathrm{E} \quad 124^{\circ} \mathrm{E} \quad 126^{\circ} \mathrm{E} \quad 128^{\circ} \mathrm{E} \quad 130^{\circ} \mathrm{E} \quad 132^{\circ} \mathrm{E}$

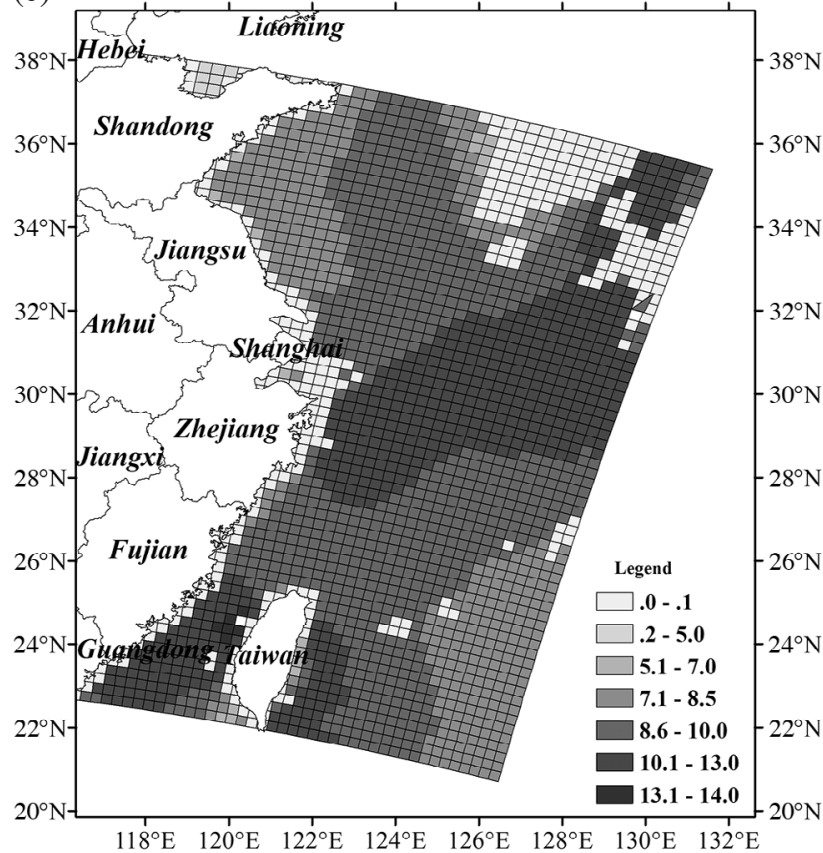

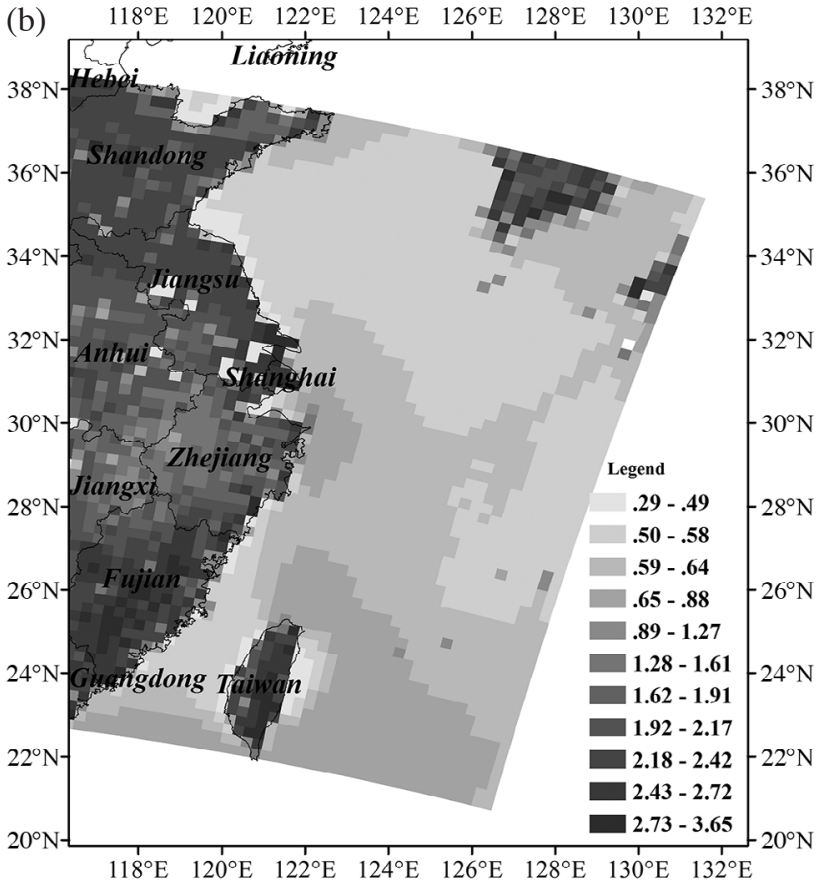

(d) $\quad 118^{\circ} \mathrm{E} \quad 120^{\circ} \mathrm{E} \quad 122^{\circ} \mathrm{E} \quad 124^{\circ} \mathrm{E} \quad 126^{\circ} \mathrm{E} \quad 128^{\circ} \mathrm{E} \quad 130^{\circ} \mathrm{E} \quad 132^{\circ} \mathrm{E}$

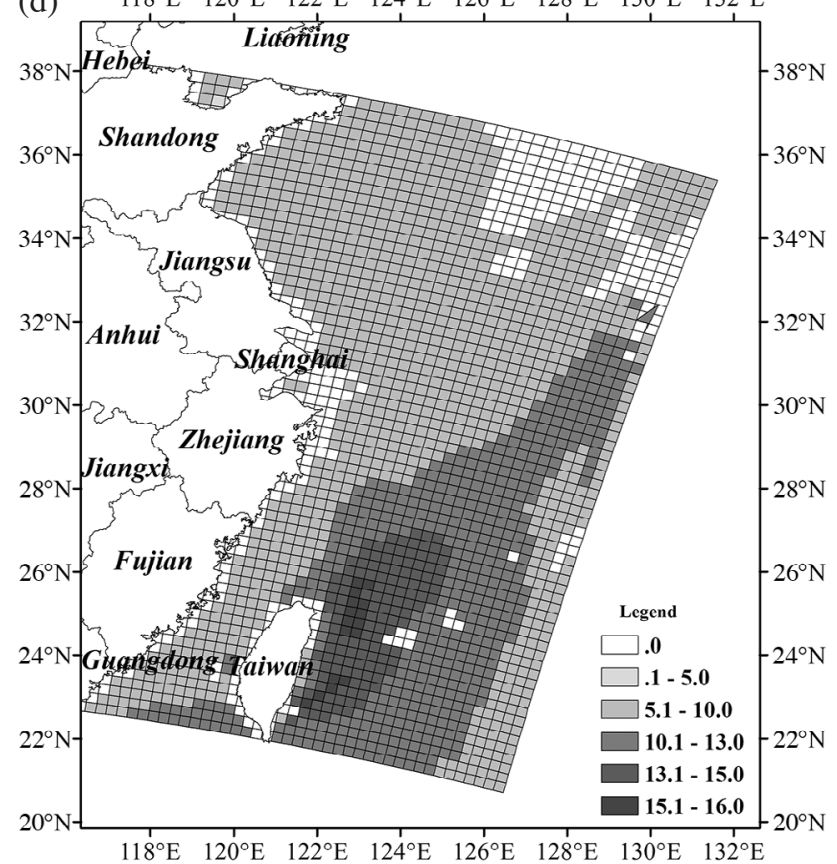

Fig. 5. $\mathrm{V}_{\mathrm{d}}$ of $\mathrm{HNO}_{3}$ in (a) January and (b) July $\left(\mathrm{cm} \mathrm{s}^{-1}\right)$ and change ratio in $\mathrm{V}_{\mathrm{d}}$ in (c) January and (d) July (\%). 
smooth sea flow was comparable with 0.26 to $0.42 \mathrm{~cm} \mathrm{~s}^{-1}$ over water surface estimated by Matsuda et al. (2001).

$V$ in Eq. (7) was replaced by $V_{d}$, the change ratio of $V_{d}$ was calculated after considering rough flow and presented in Figs. $5 \mathrm{c}$ and d. The change ratio depends on both the sea surface roughness and $\mathrm{V}_{\mathrm{dnon}}$. Thus, the areas, where largest changes in $V_{d}$ (Figs. 5c and d), did not wholly cover the areas with largest surface roughness (Fig. 3). However, $V_{d}$ still has an obvious response to sea surface rough flows with space and season. The spatial distribution of the change ratio showed that $\mathrm{V}_{\mathrm{d}}$ increased by $7-10 \%$ in most ocean areas and more than $13 \%$ in the middle East China Sea in January. $\mathrm{V}_{\mathrm{d}}$ in July increased by $8-16 \%$ in most ocean regions. In October, $\mathrm{V}_{\mathrm{d}}$ increased by more than $17 \%$ in most of the south-east parts of the East China Sea, even up to $20 \%$ in North-West sea regions to Taiwan island (figure was not presented here).

In addition to $\mathrm{HNO}_{3}$, the monthly mean change ratios of $\mathrm{V}_{\mathrm{d}}$ for $\mathrm{NO}_{2}, \mathrm{NO}$, and $\mathrm{NH}_{3}$ were listed in Table 2. Similar to $\mathrm{HNO}_{3}$, the impact on $\mathrm{V}_{\mathrm{d}}$ of $\mathrm{NH}_{3}$ from rough flows was also significant, with the annual mean increase rate of $10.1 \%$. However, $\mathrm{NO}_{2}$ and $\mathrm{NO}$ receive other resistances despite $\mathrm{R}_{\mathrm{a}}$ and $\mathrm{R}_{\mathrm{b}}$ during deposition to water surface, which reduces the impact of rough flow on $R_{a}$ and $R_{b}$, thus limits the impact on their dry deposition velocity.

\section{CONCLUSIONS AND DISCUSSION}

This study has introduced a sea surface roughness scheme with surf parameters into a dry deposition model to study the impact of rough flow on atmospheric dry deposition. The sea surface roughness increased from 0.01 to $0.03 \mathrm{~cm}$ after considering rough flow in the eastern China seas. Correspondingly, the mean value of aerodynamic $\mathrm{R}_{\mathrm{a}}$ and viscous layer $\mathrm{R}_{\mathrm{b}}$ resistances decreased $10 \%$ and $5 \%$, respectively. The mean dry deposition velocities of $\mathrm{HNO}_{3}$ with only smooth flow in the eastern China sea were $0.51,0.58$, 0.65 and $0.79 \mathrm{~cm} \mathrm{~s}^{-1}$ in January, April, July and October, respectively. Correspondingly, $\mathrm{V}_{\mathrm{d}}$ increased 9.4, 8.0, 9.5, $13.9 \%$ after considering SSRF. The impact of the SSRF on dry deposition velocity has been proved to be of importance. Hence, sea surface dynamic roughness is an important pa-

Table 2. Change ratio $\left(\Delta \mathrm{V}_{\mathrm{d}}\right)$ of dry deposition velocities due to SSRF $(\%)$.

\begin{tabular}{lcrcc}
\hline & $\mathbf{H N O}_{3}$ & $\mathbf{N H}_{3}$ & $\mathbf{N O}_{2}$ & NO \\
\hline January & 9.4 & 9.3 & 0.09 & 0.0005 \\
April & 8.0 & 8.0 & 0.05 & 0.0005 \\
July & 9.5 & 9.4 & 0.04 & 0.0004 \\
October & 13.9 & 13.7 & 0.08 & 0.0005 \\
Mean & 10.2 & 10.1 & 0.06 & 0.0005 \\
\hline
\end{tabular}

rameter studying gaseous deposition above an ocean area and its parameterization scheme needs further improvement in atmospheric deposition model.

However, since the dry deposition process is also influenced by the characteristics of substances and other factors, impacts of sea rough flow on $\mathrm{V}_{\mathrm{d}}$ vary with substance species. Substances such as $\mathrm{NO}_{2}, \mathrm{NO}$ are harder to deposit onto a sea surface and are less influenced by aerodynamic $R_{a}$ and viscous layer $R_{b}$ resistance, therefore receive smaller impact from SSRF.

Acknowledgements This work was supported by the Foundation for new teacher by the Ministry of Education (Grant Nos. 2008024610) and National Natural Science Foundation of China (Grant Nos. 41005076). Thanks for the meteorological data supported by related Meteorological Stations.

\section{REFERENCES}

Ambelas Skjøth, C., O. Hertel, and T. Ellermann, 2002: Use of the ACDEP trajectory model in the Danish nation-wide Background Monitoring Programme. Phys. Chem. Earth, 27, 1469-1477, doi: 10.1016/S14747065(02)00149-3. [Link]

Andersen, H. V. and M. F. Hovmand, 1995: Ammonia and nitric acid dry deposition and throughfall. Water Air Soil Poll., 85, 2211-2216, doi: 10.1007/BF01186162. [Link]

Asman, W. A. H. and A. J. Janssen, 1987: A long-range transport model for ammonia and ammonium for Europe. Atmos. Environ., 21, 2099-2119, doi: 10.1016/00046981(87)90344-1. [Link]

Byun, D.W. and J. K. S. Ching, 1999: Science algorithms of the EPA Models-3 Community Multiscale Air Quality (CMAQ) modeling system, United States Environmental Protection Agency (EPA), Office of Research and Development, Washington, DC 20460.

Charnock, H., 1955: Wind stress on a water surface. $Q$. J. R. Meteorol. Soc., 81, 639-640, doi: 10.1002/ qj.49708135027. [Link]

De Leeuw, G., L. Spokes, T. Jickells, C. A. Skjøth, O. Hertel, E. Vignati, S. Tamm, M. Schulz, L.-L. Sørensen, B. Pedersen, L. Klein, K. H. Schlünzen, 2003: Atmospheric nitrogen inputs into the North Sea: Effect on productivity. Cont. Shelf Res., 23, 1743-1755, doi: 10.1016/j.csr.2003.06.011. [Link]

Dudhia, J., 1996: A multi-layer soil temperature model for MM5. Preprints, The Sixth PSU/NCAR Mesoscale Model Users' Workshop, 22-24 July, Boulder, Colorado, 49-50.

Fu, Y., 2006: The study of concentration and transport characteristics of atmospheric pollutants over offshore China Sea. Master Thesis, Ocean University of China, Qingdao. (in Chinese) 
Gao, W. and M. L. Wesely, 1995: Modeling gaseous dry deposition over regional scales with satellite observations - I. Model development. Atmos. Environ., 29, 727-737, doi: 10.1016/1352-2310(94)00284-R. [Link]

Gerber, H. E, 1985: Relative - Humidity Parameterization of the Navy Aerosol Model (NAM). Naval Research Laboratory, United States, Washington, D.C., January, $16 \mathrm{pp}$.

Grell, G. A., J. Dudhia, and D. R. Stauffer, 1994: A Description of the Fifth-Generation Penn State/NCAR Mesoscale Model (MM5). Mesoscale and Microscale Meteorology Division, NCAR technical note, NCAR/ TN-389 + STR, 128 pp.

Hertel, O., J. Christensen, E. H. Runge, W. A. H. Asman, R. Berkowicz, and M. F. Hovmand, 1995: Development and testing of a new variable scale air pollution model - ACDEP. Atmos. Environ., 29, 1267-1290, doi: 10.1016/1352-2310(95)00067-9. [Link]

Hicks, B. B. and P. S. Liss, 1976: Transfer of $\mathrm{SO}_{2}$ and other reactive gases across the air-sea interface. Tellus, 28, 348354, doi: 10.1111/j.2153-3490.1976.tb00683.x. [Link]

Hong, S. Y. and H.-L. Pan, 1996: Nonlocal boundary layer vertical diffusion in a medium-range forecast model. Mon. Weather Rev., 124, 2322-2339, doi: 10.1175/152 0-0493(1996)124<2322:NBLVDI>2.0.CO;2. [Link]

Hsu, S. A., 1974: A dynamic roughness equation and its application to wind stress determination at the air-sea interface. J. Phys. Oceanogr., 4, 116-120, doi: 10.11 75/1520-0485(1974)004<0116:ADREAI>2.0.CO;2. [Link]

Huebert, B. J. and C. H. Robert, 1985: The dry deposition of nitric acid to grass. J. Geophys. Res., 90, 2085-2090, doi: 10.1029/JD090iD01p02085. [Link]

Johnson, H. K., J. Højstrup, H. J. Vested, and S. E. Larsen, 1998: On the dependence of sea surface roughness on wind waves. J. Phys. Oceanogr., 28, 1702-1716, doi: 10.1175/1520-0485(1998)028<1702:OTDOSS > 2.0.C $\mathrm{O} ; 2 .[$ Link $]$

Jurado, E., F. M. Jaward, R. Lohmann, K. C. Jones, R. Simó, and J. Dachs, 2004: Atmospheric dry deposition of persistent organic pollutants to the Atlantic and inferences for the global oceans. Environ. Sci. Technol., 38, 55055513, doi : 10.1021/es049240v. [Link]

Lin, H. and G. Chen 2002: Application of TOPEX altimeter on the observation of the seasonal change of wind speed and significant wave height of global sea surface. Chinese Sci. Bull., 4, 411-416. (in Chinese)

Lin, T., Y. Zhang, X. Yang, H. Zhao, X. Li, and X. Ji , 2004: The application of MM5 model to predict sea surface wind field. Mar. Forecast., 21, 1-9, doi: 10.3969/j. issn.1003-0239.2004.04.001. (in Chinese) [Link]

Liu, J. and L. Sun, 2000: Characteristic analysis of wind field and sea wave field in the western part of the $\mathrm{N}$. Pacfic Ocean.Mar.Forecast., 17, 54-62, doi: 10.3969/j. issn.1003-0239.2000.03.008. (in Chinese) [Link]

Ma, J. and S. M. Daggupaty, 2000: Effective dry deposition velocities for gases and particles over heterogeneous terrain. J. Appl. Meteorol., 39, 1379-1390, doi: 10.11 75/1520-0450(2000)039<1379:EDDVFG>2.0.CO;2. [Link]

Matsuda,K., N. Fukuzaki, and M. Maeda, 2001: A case study on estimation of dry deposition of sulfur and nitrogen compounds by inferential method. Water Air Soil Poll., 130, 553-558, doi: 10.1023/A:1013842914707. [Link]

Meyers, T. P., B. J. Huebert, and B. B. Hicks, 1989: $\mathrm{HNO}_{3}$ deposition to a deciduous forest. Bound.-Layer Meteor., 49, 395-410, doi: 10.1007/BF00123651. [Link]

Nho-Kim, E. Y., M. Michou, and V.-H. Peuch, 2004: Parameterization of size-dependent particle dry deposition velocities for global modeling. Atmos. Environ., 38, 1933 1942, doi: 10.1016/j.atmosenv.2004.01.002. [Link]

Pan, Y., J. Nin, and W. Sha, 2005: Intercomparison of three sea surface aerodynamic roughness schemes in COARE algorithm. Acta Oceanol. Sin., 27, 163-169. (in Chinese)

Qi, J., P. Li, X. Li, L. Feng, and M. Zhang, 2005: Estimation of dry deposition fluxes of aerosol particles in the Qingdao area. Period. Ocean Univ. China, 35, 445450. (in Chinese)

Rendell, A. R., C. J. Ottley, T. D. Jickells, and R. M. Harrison, 1993: The atmospheric input of nitrogen species to the North Sea. Tellus B, 45, 53-56, doi: 10.1034/j.16000889.1993.00005.x. [Link]

Sievering, H., T. Kelly, G. McConville, C. Seibold, and A. Turnipseed, 2001: Nitric acid dry deposition to conifer forests: Niwot Ridge spruce-fir-pine study. Atmos. Environ., 35, 3851-3859, doi: 10.1016/S13522310(01)00156-X. [Link]

Slinn S. A. and W. G. N. Slinn, 1980: Predictions for particle deposition on natural waters. Atmos. Environ., 14, 10131016, doi: 10.1016/0004-6981(80)90032-3. [Link]

Smith, S. D., R. J. Anderson, W . A. Oost, C. Kraan, N. Maat, J. DeCosmo, K. B. Katsaros, K. L. Davidson, K. Bumke, L. Hasse, and H. M. Chadwick, 1992: Sea surface wind stress and drag coefficients: The hexos results. Bound.-Layer Meteor., 60, 109-142, doi: 10.1007/ bf00122064. [Link]

Taylor, P. K. and M. J. Yelland, 2001: The dependence of sea surface roughness on the height and steepness of the waves. J. Phys. Oceanogr., 31, 572-590, doi: 10.1 175/1520-0485(2001)031<0572:TDOSSR>2.0.CO;2. [Link]

Uz, B. M., M. A. Donelan, T. Hara, and E. J. Bock, 2002: Laboratory studies of wind stress over surface waves. Bound.-Layer Meteor., 102, 301-331, doi: 10.1023/A:1013119313063. [Link]

Walcek, C. J., R. A. Brost, J. S. Chang, and M. L. Wesely, 1986: $\mathrm{SO}_{2}$, sulfate and $\mathrm{HNO}_{3}$ deposition velocities 
computed using regional landuse and meteorological data. Atmos. Environ., 20, 949-964, doi: 10.1016/00046981(86)90279-9. [Link]

Wan, X., Z. Wu, Z. Chang, and X. Zhang, 2002: Reanalysis of atmospheric flux of nutrients to the South Yellow Sea and the East China Sea. Mar. Environ. Sci., 21, 14-18, doi: 10.3969/j.issn.1007-6336.2002.04.004. (in Chinese) [Link]

Wang, Z., 2006: Study on dry deposition model of atmospheric aerosol and dry deposition fluxes of elements loaded on aerosol to the sea near Qingdao area, Ocean University of China. (in Chinese)

Wesely, M. L., 1989: Parameterization of surface resistances to gaseous dry deposition in regional-scale numerical models. Atmos. Environ., 23, 1293-1304, doi: 10.1016/0004-6981(89)90153-4. [Link]

Williams, R. M., 1982: A model for the dry deposition of particles to natural water surfaces. Atmos. Environ., 16, 1933-1938, doi: 10.1016/0004-6981(82)90464-4. [Link]

Wu, J., 1982: Wind-stress coefficients over sea surface from breeze to hurricane. J. Geophys. Res., 87, 9704-9706, doi: 10.1029/JC087iC12p09704. [Link]

Zhang, Y., Q. Yu, W. Ma, and L. Chen, 2010: Atmospheric deposition of inorganic nitrogen to the eastern China seas and its implications to marine biogeochemistry. J. Geophys. Res., 115, D00K10, doi: 10.1029/2009JD012814. [Link]

Zhang. Y., T. Wang, Z. Hu, and C. Xu, 2004: Temporal variety and spatial distribution of dry deposition velocities of typical air pollutants over different landuse types. Clim. Environ. Res., 9, 591-604, doi: 10.3878/j. issn.1006-9585.2004.04.05. (in Chinese) [Link]

Zhang, Y., T. J. Wang, and L.-M. Chen, 2007: Using SubGrid Scale Method to Quantify Atmospheric Deposition of Sulfur in East China. Terr. Atmos. Ocean. Sci., 18, 1051-1065, doi: 10.3319/TAO.2007.18.5.1051(A). [Link]

Zhou, L. and P. Guo, 2005: Derivation of sea surface roughness from wind speed estimated by satellite altimnter. Trans. Oceanol. Limnol., 4, 10-14, doi: 10.3969/j.issn. 1003-6482.2005.04.002. (in Chinese) [Link] 